\title{
Lab-Scale Production of Bacillus atrophaeus' Spores by Solid State Fermentation in Different Types of Bioreactors
}

\author{
Sandra Regina Barroso Ruiz Sella ${ }^{1,2}$, Belquis Palácio Guizelini ${ }^{2}$, Luciana Porto de Souza \\ Vandenberghe $^{2}$, Adriane Bianchi Pedroni Medeiros ${ }^{2}$ and Carlos Ricardo Soccol \\ ${ }^{l}$ Centro de Produção e Pesquisa de Imunobiológicos; Secretaria de Estado da Saúde; Piraquara - Paraná - Brasil. \\ ${ }^{2}$ Departamento de Engenharia; Departamento de Engenharia de Bioprocessos e Biotecnologia; Universidade \\ Federal do Paraná; Curitiba - Paraná - Brasil
}

\begin{abstract}
Studies were conducted to evaluate Bacillus atrophaeus spores' production by solid-state fermentation (SSF) using sugarcane bagasse as support and soybean molasses as substrate at lab-scale in column bioreactors (forced aeration), plastic bags and Erlenmeyer flasks (aeration by diffusion). Different moisture contents (84\%, 86\% and $88 \% ; 89 \%, 91 \%$ and $93 \%)$ and aeration rates $(30 \mathrm{~mL} / \mathrm{min}, 45 \mathrm{~mL} / \mathrm{min}, 60 \mathrm{~mL} / \mathrm{min}$ and $90 \mathrm{~mL} / \mathrm{min})$ were studied. The best condition for spore production $\left(3.3 \times 10^{10} \mathrm{CFU.g-}{ }^{1}\right.$ dry matter) in column bioreactor was $80 \%$ of initial humidity and no aeration. In Erlenmeyer flasks and plastic bags the best sporulation production reached 1.7 up to $4.7 \times 10^{10}$ CFU. $g^{-1}$ dry matter with $88-93 \%$ of initial moisture. The aeration rate had no significant effect on the spore yield. The initial moisture had a significant effect depending on the bioreactor type. Sporulation kinetic's assay was carried out and it showed the possibility to reduce the time of spore formation in two days.
\end{abstract}

Key words: Bacillus atrophaeus, spores, solid state fermentation, column bioreactor, biofilm

\section{INTRODUCTION}

Bacterial spores are differentiated cell types, highly specialized, and designed for the survival on adverse conditions. Its dormancy and resistance are responsible for some serious problems in food-, medicare-, paper-, and spaceindustry. Bacillus atrophaeus is a Gram-positive, facultative anaerobic rod that makes endospores. It has been used as a biological indicator of sterilization assurance (Christensen and Kristensen, 1979; AAMI, 1994; Fritze and Pukall, 2001; USP 29, 2005), evaluation of agents for cleaning and disinfection (Blakistone et al., 1999;
Penna et al., 2001), as well as an indicator organism in drinking water treatment (Gale et al., 2002). Due to its similar particle size and dispersal characteristics to those of Bacillus antrhacis, has been used as a biological tracer for anthrax (HSTAT, 2002).

It has been well established that bacterial spore properties are affected by the conditions during sporulation. In most studies, spores are routinely produced from fortified agar. Sella et al. (2008) had demonstrated the use of solid state fermentation (SSF) with agro-industrial residues as a cost-effective method for Bacillus atrophaeus' heat resistant spores' production.

\footnotetext{
* Author for correspondence: soccol@ufpr.br
} 
SSF process can be defined as microbial growth on solid particles without the presence of free water. The water present in SSF systems exists in a complexed form within the solid matrix, as a thin layer either absorbed to the surface of the particles or less tightly bound within the capillary regions of the solid (Raimbault,1988). Environmental factors such as concentrations of nutrients, moisture, water activity and oxygen levels significantly can affect microbial growth and product formation (Mudgett, 1986). Usually aeration also has very important effects on hydration properties and heat regulation in SSFs. The effect of defined SSF conditions and media to link specific bioreactor use with Bacillus atrophaeus sporogenesis has not been studied systematically.

The aim of the present work was to evaluate the influence of aeration and moisture on Bacillus atrophaeus' spores' SSF production using different types of bioreactors to define the best parameters for growth kinetic study.

\section{MATERIALS AND METHODS}

\section{Microorganism}

A strain of Bacillus atrophaeus ATCC 9372, Bach-1403349, obtained from standard strains supplied by Instituto Nacional de Controle de Qualidade em Saúde (INCQS/MS, Brazil), was used. Stock cultures and stored at $-80^{\circ} \mathrm{C}$ in $20 \%$ glycerol. Working cultures were maintained on standard tryptone soy agar (TSA) and were sub cultured periodically at $36^{\circ} \mathrm{C}$ for $24-48 \mathrm{~h}$ and were stored a $4^{\circ} \mathrm{C}$.

\section{Inoculum}

For inoculum preparation, $100 \mu \mathrm{L}$ of spore suspension-batch: 01/06-CPPI-was inoculated in three tubes, each one with $30 \mathrm{~mL}$ of tested medium. These media were incubated for $18 \mathrm{~h}$ at $36{ }^{\circ} \mathrm{C}$. The media used were standard medium: tryptone soy broth - TSB (USP 29, 2005) and complex medium: soybean molasses $\left(\sim 75^{\circ}\right.$ Brix $)$, $2.0 \% \mathrm{w} / \mathrm{v}$ and tryptone, $4.0 \% \mathrm{w} / \mathrm{v}$.

\section{Sporulation}

For SSF sporulation sugarcane bagasse was used as support. It was supplied by COCAMAR (Cianorte-Brazil), milled, washed once with tap water and twice with distillated water. The washed bagasse was dried on trays for $24 \mathrm{~h}$ at $90^{\circ} \mathrm{C}$ in an air oven. The dry bagasse was sieved to obtain a particle size between $0.85 \mathrm{~mm}$ to $1.18 \mathrm{~mm}$. The substrate consisted of: soybean molasses $2.0 \%$, supplemented with sporulation inductor salts $\left(\mathrm{K}_{2} \mathrm{HPO}_{4} . \mathrm{H}_{2} \mathrm{O}, 0.005 \%\right.$; $\mathrm{MnSO}_{4} . \mathrm{H}_{2} \mathrm{O}, 0.004 \%$; $\mathrm{CaCl}_{2} \cdot 6 \mathrm{H}_{2} \mathrm{O}, 0.004 \%$; $\mathrm{MgSO}_{4} .7 \mathrm{H}_{2} \mathrm{O}, 0.005 \%$ ). Soybean molasses $\left(\sim 75^{\circ}\right.$ Brix) was supplied by IMCOPA (Araucária-Brazil) with the composition: total sugar, 50.8\%; protein, 5.1\%; lipids, $0.3 \%$; $\mathrm{pH}, 6.1$. The initial substrate $\mathrm{pH}$ was adjusted to 8.0 before sterilization. The moisture content was adjusted with distilled water before autoclaving. The flasks with SSF medium were autoclaved at $121^{\circ} \mathrm{C}$ for $15 \mathrm{~min}$. The inoculum size was $3 \%$ (v/v substrate) or $10^{7} \mathrm{CFU} . \mathrm{g}^{-1}$ dry matter. Calculated inoculum volumes were mixed thoroughly with the autoclaved medium in a sterile laminar flow chamber. SSF was carried out at $36^{\circ} \mathrm{C}$. Different quantities of dry substrate were used for the different bioreactors: $5 \mathrm{~g}$ for Erlenmeyer flasks; $10 \mathrm{~g}$ for column bioreactors and $12 \mathrm{~g}$ for plastic bags. The fermented bagasse was mixed with $0.02 \mathrm{M}$ calcium acetate solution with Tween $80(0.01 \%) \mathrm{pH}$ adjusted to 9.7 and sterile glass beds for $1 \mathrm{~h}$, before filtration. All spores' suspensions were filtered through gauze tissue and, subsequently, washed three times by centrifugation at $2,500 \mathrm{rpm}(1.048 \mathrm{~g})$ for $20 \mathrm{~min}$ at $4^{\circ} \mathrm{C}$ with cold, sterile $0.02 \mathrm{M}$ calcium acetate solution adjusted to pH 9.7 (Hoxey et al., 1985; Penna et al., 1996). Spore suspensions kept in flasks were subjected to a heat shock $\left(80{ }^{\circ} \mathrm{C}, 10\right.$ $\mathrm{min}$ ) and were stored at $4{ }^{\circ} \mathrm{C}$. Viable spore counts were done by serial decimal dilutions in distilled sterile water and $50 \mu \mathrm{L}$ of each dilution was inoculated on a tryptone soy agar plate surface, in duplicate. Plates were incubated overnight at 36 ${ }^{\circ} \mathrm{C}$. For the media and the results analyses were considered the U.S. Pharmacopeia requirements that allowed a $50 \%$ up to $300 \%$ as permissible variation of viable spores' counts enumeration.

\section{SSF in column bioreactor}

It was carried out in glass columns with a $4 \mathrm{~cm}$ diameter and $20 \mathrm{~cm}$ length (volume of $250 \mathrm{~mL}$ ) filled with the inoculated SSF medium. The temperature of the water bath was maintained at $36{ }^{\circ} \mathrm{C}$ and the columns were connected in the bottom with a water saturated air flow. Fermentation was carried out for nine days. In the first assay a mixed 2 and 3 levels factorial experimental design with 2 factors and 1 central point was used in order to study the effects of 
aeration rate -30 up to $90 \mathrm{~mL} / \mathrm{min}$ - and the, moisture content- 86 to $90 \%$ (Table 1). In the second assay a $2^{2}$ factorial experimental design with 2 factors, 2 levels and 2 central points - was used in order to study the aeration rate - 0 up to 90
$\mathrm{mL} / \mathrm{min}$ - and the initial humidity of the substrate 84 up to $88 \%$ - effects (Table 2). As control the same conditions of fermentation was carried out in $250 \mathrm{~mL}$ Erlenmeyer flasks without aeration.

Table 1 - Mixed $2^{2}$ and $2^{3}$ experimental design for testing Bacillus atrophaeus spores production by SSF in columns with differents initial moisture and aeration rates.

\begin{tabular}{cccc}
\hline Run & Replicate & Moisture (\%) & Aeration rate $(\mathbf{m L} / \mathbf{m i n})$ \\
\hline 1 & Central point 1 & 88 & 60 \\
2 & 1 & 90 & 90 \\
3 & 1 & 90 & 30 \\
4 & 1 & 86 & 30 \\
5 & 1 & 86 & 90 \\
6 & 1 & 88 & 90 \\
7 & 1 & 88 & 30 \\
8 & Central point 2 & 88 & 60 \\
\hline
\end{tabular}

Table 2- $2^{2}$ experimental design for testing Bacillus atrophaeus spores production by SSF in columns with differents initial moisture and aeration rates

\begin{tabular}{cccc}
\hline Run & Replicate & Moisture (\%) & Aeration rate $(\mathbf{m L} / \mathbf{m i n})$ \\
\hline 1 & 1 & 88 & 90 \\
2 & 1 & 88 & 45 \\
3 & 1 & 88 & 0 \\
4 & Central point 1 & 86 & 45 \\
5 & Central point 2 & 86 & 45 \\
6 & 1 & 84 & 90 \\
7 & 1 & 84 & 45 \\
8 & 1 & 84 & 0 \\
\hline
\end{tabular}

Effects of bioreactor, substrate concentration, inoculum medium and incubation time

This study aimed at determining the bioreactor influence, the best substrate concentration $(2 \%$ or $3 \%$ ), inoculum medium (standard or complex) and incubation time ( 7 or 9 days) (Table 3 ). A $2^{2}$ full factorial experimental design with 2 factors and 2 levels was used. The initial humidity was $91 \%$ and a polyethylene bags $(39 \times 50 \mathrm{~cm})$, where the culture medium was prepared and autoclaved, was tested as bioreactor. The bags were sealed after inoculation.

\section{Kinetics}

Kinetics of spore production was followed for 9 days with the conditions: $91 \%$ initial moisture content: soybean molasses, $2.0 \%(\mathrm{w} / \mathrm{v})$ and tryptone, $4.0 \%(\mathrm{w} / \mathrm{v})$ as inoculum medium, Erlenmeyer flasks and plastic bags as bioreactor. 
Table 3- Effects of bioreactor, substrate concentration, inoculum medium and incubation time assay's for testing Bacillus atrophaeus spores production.

\begin{tabular}{|c|c|c|c|c|}
\hline Run & Bioreactor & Inoculum medium & $\begin{array}{c}\text { Soybean molasses } \\
(\%)\end{array}$ & $\begin{array}{c}\text { Incubation time } \\
\text { (days) }\end{array}$ \\
\hline 1 & Erlenmeyer flask & Standard & 2 & 7 \\
\hline 2 & & & 3 & 7 \\
\hline 3 & & & 2 & 9 \\
\hline 4 & & & 3 & 9 \\
\hline 5 & & Complex & 2 & 7 \\
\hline 6 & & & 3 & 7 \\
\hline 7 & & & 2 & 9 \\
\hline 8 & & & 3 & 9 \\
\hline 9 & Plastic bag & Standard & 2 & 7 \\
\hline 10 & & & 3 & 7 \\
\hline 11 & & & 2 & 9 \\
\hline 12 & & & 3 & 9 \\
\hline 13 & & Complex & 2 & 7 \\
\hline 14 & & & 3 & 7 \\
\hline 15 & & & 2 & 9 \\
\hline 16 & & & 3 & 9 \\
\hline
\end{tabular}

\section{Analytical Methods}

Reducing sugars were measured by Somogyi and Nelson (Nelson, 1944). The parameters $\mathrm{pH}$ and moisture were determined as described by Soccol et al., (1995). The water activity $\left(\mathrm{a}_{\mathrm{w}}\right)$ measurements were determined at $21-22^{\circ} \mathrm{C}$, in triplicate, using an AquaLab CX-2 water activity meter (Decagon Devices, Pullman).

\section{Statistical Analysis}

Analyses were done using the software Statistica 6.0 (StatSoft Inc.). All experiments were realized in duplicate under aseptic conditions. The results were compared by ANOVA. Significant differences were accepted at the level of $\mathrm{p}<0.005$.

\section{RESULTS}

For optimum SSF sporulation in column, differents relations between aeration rate -30 up to $90 \mathrm{~mL} / \mathrm{min}$ - and moisture content were studied. In the first column fermentation assay free water was observed during incubation time when the moisture content exceeded $88 \%$, due to saturation capacity of the solid matrix. This weakened the SSF process that is defined by Raimbault (1988) as microbial growth on solid particles without the presence of free water. Results revealed that at the end of the incubation time the water activities at all substrate moisture contents wet-basis were essentially identical (0.970). For the fermented mass from the columns the $\mathrm{pH}$ of the culture had an increase from 0.6 up to 2.0 in response to metabolic activities, yet the amount of moisture content (wet-basis) differed from $1 \%$ up to $5 \%$ and the maximum spore yield observed was $6.1 \times 10^{7}$ CFU.g ${ }^{-1}$ dry matter in the no aerated column and $88 \%$ as initial moisture. For the fermented mass from the Erlenmeyer flasks the $\mathrm{pH}$ of the culture had an increase from 1.2 up to 2.7, the amount of moisture content (wet-basis) differed from 3\% up to $27 \%$, the maximum spore yield observed was $1.7 \times 10^{9}$ CFU.g ${ }^{-1}$ dry matter in $90 \%$ as initial moisture and no free water formation were observed (Table 4). 
Table 4 - Bacillus atrophaeus spores production by SSF in columns and Erlenmeyer flasks with differents initial moisture and aeration rates.

\begin{tabular}{ccccccc}
\hline Assay & $\begin{array}{c}\text { Moisture } \\
(\boldsymbol{\%})\end{array}$ & $\begin{array}{c}\text { Aeration } \\
\text { rate } \\
(\mathbf{m L / m i n})\end{array}$ & $\mathbf{p H}_{\boldsymbol{i}}$ & $\begin{array}{c}\text { Moisture } \\
(\boldsymbol{\%})\end{array}$ & $\mathbf{p H}_{\mathbf{f}}$ & $\begin{array}{c}\text { Spores } \\
\left(\mathbf{C F U} \mathbf{g}^{-1}\right)\end{array}$ \\
\hline C1 & 88 & 60 & 6.4 & 87 & 8.0 & $2.6 \times 10^{7}$ \\
C2 & 90 & 90 & 6.1 & 87 & 7.3 & $2.1 \times 10^{6}$ \\
C3 & 90 & 30 & 6.1 & 87 & 6.6 & $1.8 \times 10^{6}$ \\
C4 & 86 & 30 & 6.0 & 81 & 6.9 & $3.7 \times 10^{6}$ \\
C5 & 86 & 90 & 6.0 & 83 & 7.8 & $3.9 \times 10^{6}$ \\
C6 & 88 & 90 & 6.4 & 87 & 7.3 & $3.1 \times 10^{7}$ \\
C7 & 88 & 30 & 6.4 & 84 & 6.6 & $2.0 \times 10^{7}$ \\
C8 & 88 & 0 & 6.4 & 85 & 7.9 & $6.1 \times 10^{7}$ \\
E1 & 86 & - & 6.4 & 61 & 7.9 & $1.1 \times 10^{8}$ \\
E2 & 88 & - & 5.9 & 78 & 8.8 & $6.9 \times 10^{8}$ \\
E3 & 90 & - & 6.1 & 87 & 7.3 & $1.7 \times 10^{9}$ \\
\hline C- column & & &
\end{tabular}

$\mathrm{C}=$ column.

$\mathrm{E}=$ Erlenmeyer flask.

$\mathrm{pH}_{\mathrm{i}}=\mathrm{pH}$ after substrate sterilization (the $\mathrm{pH}$ was adjusted only before sterilization to avoid contamination).

$\mathrm{pH}_{\mathrm{f}}=$ final $\mathrm{pH}$.

The main effects plot of columns biomass (Fig 1) presents $88 \%$ for moisture content optimum value and no detectable differences in total spore formation between the 30 and $90 \mathrm{~mL} / \mathrm{min}$ aeration rate.

Under the studied conditions for forced aeration from 30 up to $90 \mathrm{~mL} / \mathrm{min}$, and aeration by diffusion in Erlenmeyer flask, the SSF sporulation results in the box plot analysis (Fig 2) showed that aeration by diffusion gave better spore yield in approximately $2 \log$ (100 times) higher than the production in column, that may have been caused by partial loss of bacterial growth due to the formation of free water.

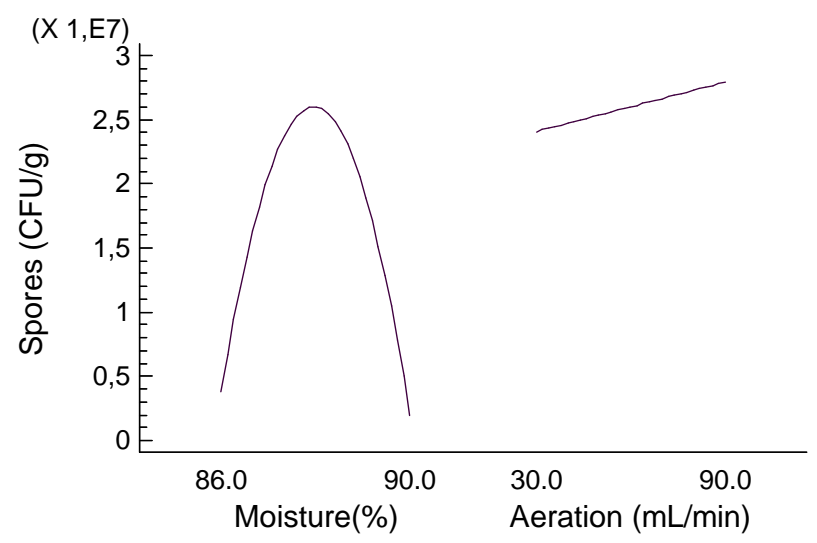

Figure 1 - Main effects of moisture and aeration rate on columns spores' production (forced aeration). 


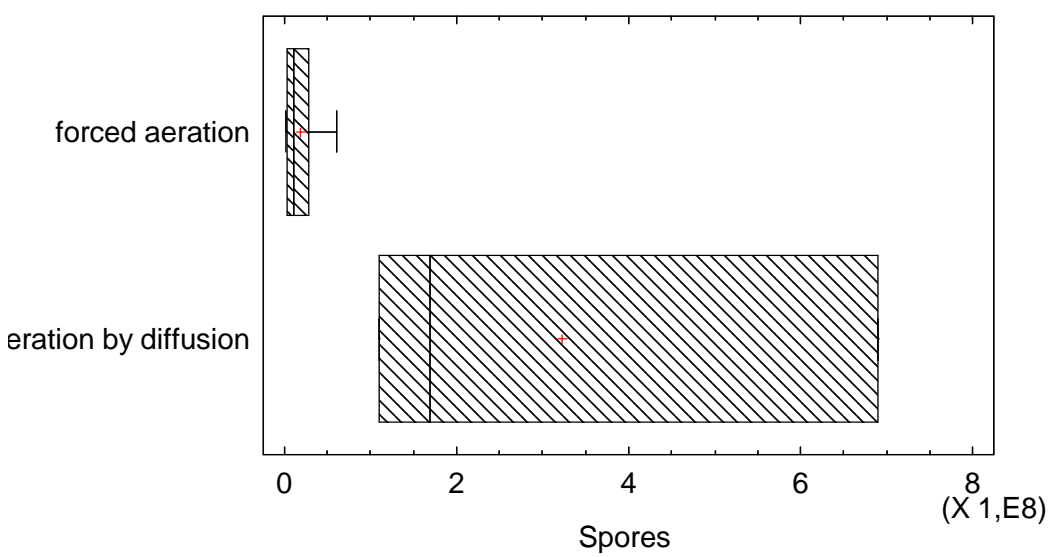

Figure 2 - Comparative Bacillus atrophaeus spores production in column bioreactors with forced aeration (30 up to $90 \mathrm{~mL} / \mathrm{min}$ ) and Erlenmeyer flasks (aeration by diffusion) with differents initial moisture (86 up to $90 \%$ ).

In the second column fermentation experiment, over the range of initial moisture contents of 84$88 \%$ (w/w wet basis) and aeration rate of $0-90$ $\mathrm{mL} / \mathrm{min}$, the highest spore content $3.7 \times 10^{10} \mathrm{CFU}$. $\mathrm{g}^{-1}$ dry matter occurred at $88 \%$ initial moisture and no aeration (Table 5). The moisture content fell from $2 \%$ up to $6 \%$ and $\mathrm{pH}$ increased from 1.3 up to 1.9 during the fermentation time.

Table 5 - Bacillus atrophaeus spores production by SSF in columns and Erlenmeyer flasks with differents initial moisture and aeration rates

\begin{tabular}{ccccccc}
\hline Assay & $\begin{array}{c}\text { Moisture } \\
(\mathbf{\%})\end{array}$ & $\begin{array}{c}\text { Aeration } \\
\text { rate } \\
(\mathbf{m L / m i n})\end{array}$ & $\mathbf{p H}_{\mathbf{i}}$ & $\begin{array}{c}\text { Moisture } \\
\mathbf{( \% )}\end{array}$ & $\mathbf{p H}_{\mathbf{f}}$ & $\begin{array}{c}\text { Spores } \\
\left(\mathbf{C F U} \cdot \mathbf{g}^{-1}\right)\end{array}$ \\
\hline C1 & 88 & 90 & 5.7 & 86 & 7.0 & $1.7 \times 10^{10}$ \\
C2 & 88 & 45 & 5.7 & 84 & 7.6 & $1.7 \times 10^{10}$ \\
C3 & 88 & 0 & 5.7 & 82 & 7.0 & $3.7 \times 10^{10}$ \\
C4 & 86 & 45 & 5.7 & 82 & 7.2 & $1.7 \times 10^{10}$ \\
C5 & 86 & 45 & 5.7 & 80 & 7.0 & $6.7 \times 10^{9}$ \\
C6 & 84 & 90 & 5.7 & 82 & 7.6 & $6.8 \times 10^{8}$ \\
C7 & 84 & 0 & 5.7 & 77 & 7.0 & $3.3 \times 10^{7}$ \\
C8 & 84 & 45 & 5.7 & 80 & 7.6 & $6.5 \times 10^{7}$ \\
E1 & 84 & - & 5.7 & 75 & 7.5 & $3.9 \times 10^{7}$ \\
E2 & 86 & - & 5.7 & 75 & 7.2 & $1.2 \times 10^{7}$ \\
E3 & 88 & - & 5.7 & 73 & 7.0 & $1.9 \times 10^{10}$ \\
E4 & 90 & - & 5.9 & 73 & 7.0 & $2.0 \times 10^{10}$ \\
\hline
\end{tabular}

$\mathrm{C}=$ column.

$\mathrm{E}=$ Erlenmeyer flask.

$\mathrm{pH}_{\mathrm{i}}=\mathrm{pH}$ after substrate sterilization (the $\mathrm{pH}$ was adjusted only before sterilization to avoid contamination).

$\mathrm{pH}_{\mathrm{f}}=$ final $\mathrm{pH}$.

The analysis of variance (ANOVA), of these results showed statistically significant positive effect for substrate moisture content $(p=0.0073)$, no significant effect for aeration rate $(p=0.1483)$ and $\mathrm{R}^{2}$ 94.6.
In Erlenmeyer flasks (control) the $\mathrm{pH}$ of the culture had an increase from 1.1 up to 1.9, the amount of moisture content (wet basis) differed from $9 \%$ up to $15 \%$, and the maximum spore yield 
observed was $2.0 \times 10^{10} \mathrm{CFU} . \mathrm{g}^{-1}$ dry matter at $90 \%$ initial moisture.

Under the studied conditions for forced aeration in columns, 0 up to $90 \mathrm{~mL} / \mathrm{min}$, aeration by diffusion in columns and in Erlenmeyer flasks, the SSF sporulation resulted in the box plot analysis (Fig 3) showed no differences in spore yield.

The effects of bioreactor's type and its relation with nutrient concentration level, inoculum medium and duration of cultivation on total end spore formation are presented in Fig. 4.

The results were stratified by the variables and runs a t-test were applied to compare the means. There were not a statistically significant difference between the means of the Erlenmeyer and plastic bags $(p$-value $=0.0921)$, standard and complex inoculum medium ( $p$-value $=0.1491)$, substrate molasses concentration $(p$-value $=0.0826)$ and incubation time $(p$-value $=0.781165)$.

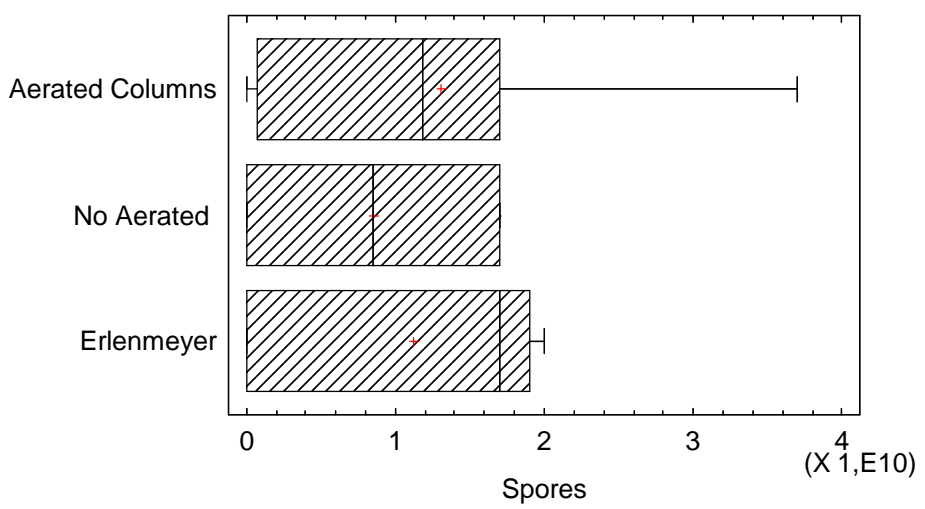

Figure 3 - Comparative Bacillus atrophaeus spores production in column bioreactors (forced aeration - 45 up to $90 \mathrm{~mL} / \mathrm{min}$ ), column bioreactors without forced aeration and Erlenmeyer flasks (aeration by diffusion).

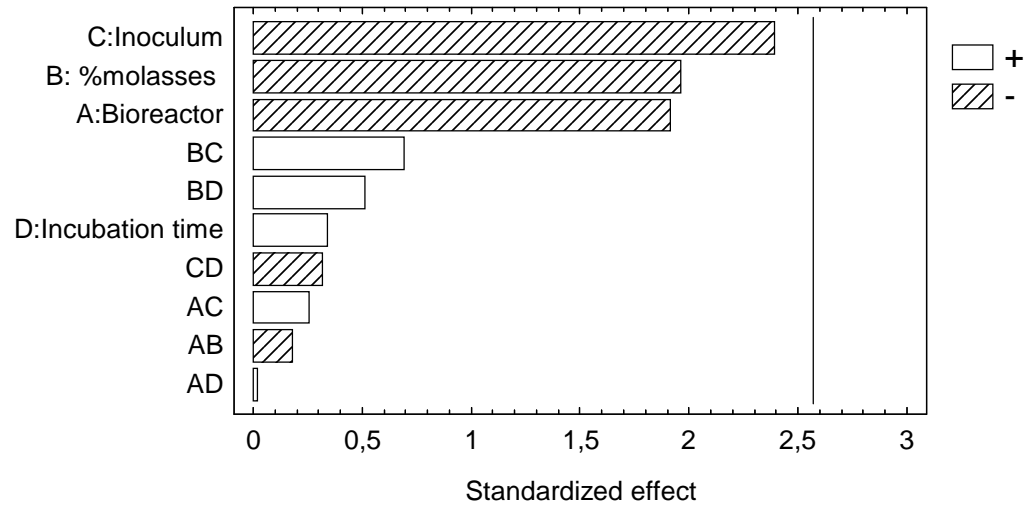

Figure 4 - Pareto Chart of Effects for Bacillus atrophaeus spore production without forced aeration. Variables: inoculum medium (industrialized and complex), \% molasses (2 and 3\%), bioreactor (plastic bag and Erlenmeyer flask) and incubation time (7 and 9 days). 
The mean of all results showed that the $\mathrm{pH}$ decreases after sterilization process from $8.0 \pm 0.1$ up to $5.8 \pm 0,1$, and reached at $8.0 \pm 0.3$ before 7 days of fermentation and decrease again to $7.8 \pm$ 0.4 at the ninth day, the amount of moisture content (wet-basis) no differed, and the sugar

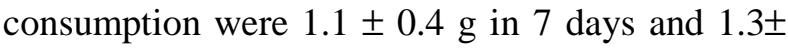
$0.5 \mathrm{~g}$ in 9 days incubation time.

Knowing that the growth rate of the microorganism depends on the local environmental conditions (Redmond et al., 2004; Vries et al., 2005), the evaluation of spore's yields from Erlenmeyer flasks and plastic bags fermentation was done by comparative kinetic studies. During fermentation kinetic in Erlenmeyer flasks the $\mathrm{pH}$ of the culture had an increased 1.6 in seven days incubation and decrease 0.5 from the 7th to the 9th incubation day, the water activity of the substrate (0.97) did not change, the amount of moisture content (wet-basis) has remained at $87 \%$, the difference between the calculated moisture (91\%) and the obtained (87\%) is due to loss of water during sterilization process. The reducing sugars consummation was $0.83 \mathrm{~g}$. Fermentation kinetic in plastic bags showed that the $\mathrm{pH}$ of the culture had an increase 1.4 in seven days incubation and decrease 0.2 from the 7 th to the 9 th incubation day, the water activity of the substrate (0.7) did not change too, the amount of moisture content (wet basis) has remained at $89 \%$, and the reducing sugars consummation was $0.89 \mathrm{~g}$, showing similarity in both processes.

The kinetic results demonstrated an increase in total biomass after $24 \mathrm{~h}$ of incubation of 3 up to 4 $\operatorname{logs}$ (thousand to ten thousand times), which corresponds to the exponential growth phase of vegetative cells. The sporulation began approximately $24 \mathrm{~h}$ after incubation and was stabilized after $168 \mathrm{~h}$ (7 days). The observed increase in the production of spores between the seventh and ninth days of incubation ( $276 \mathrm{~h}$ ) was less than $1 \mathrm{log}$, confirming the data obtained previously and allowing the reduction of incubation time in 2 days, without compromising process productivity (Fig 5 and Fig 6).

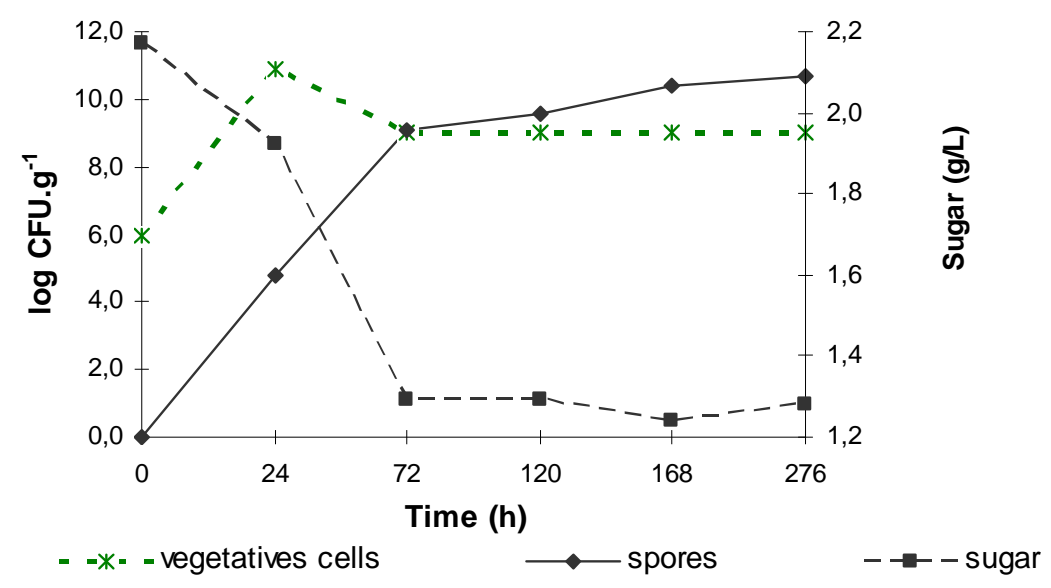

Figure 5 - Bacillus atrophaeus kinetics' spores production by SSF in plastic bags 


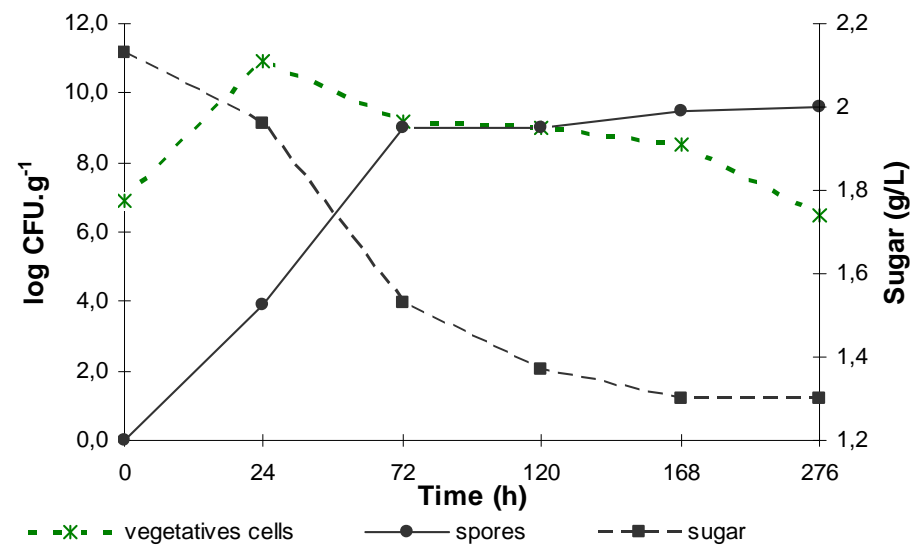

Figure 6 - Bacillus atrophaeus kinetics' spores production by SSF in Erlenmeyer flasks.

The spores obtained from both cultures, when germinated in tryptone soy agar (TSA) have mucoid colonies, large, and no delimited. The morphology was different from that obtained from standard strain spores cultivate in sporulation agar which are smaller and well defined (Fig. 7). Branda et al (2001) described this formation of colonies in wild strains of Bacillus subtilis, and joined its morphology with the production of surfactin and exopolysaccharides. These characteristics are also related to the use of a metabolic pathway that offers additional growth in structured communities, called biofilms, and the formation of spores through air structures called fruiting bodies. The $72 \mathrm{~h}$ in liquid medium tryptone soy broth (TSB) confirmed the ability of these cells to germinate and reproduce it in the form of biofilm, through the formation of a thick film on the surface and the formation of spores within $24 \mathrm{~h}$ of cultivation. The microscopic observation of this growth, stained by Gram method, showed the formation of chains and isolated cells, while the colonies from spores grown on agar for sporulation have only isolated cells. All this observations suggested the biofilm formation.

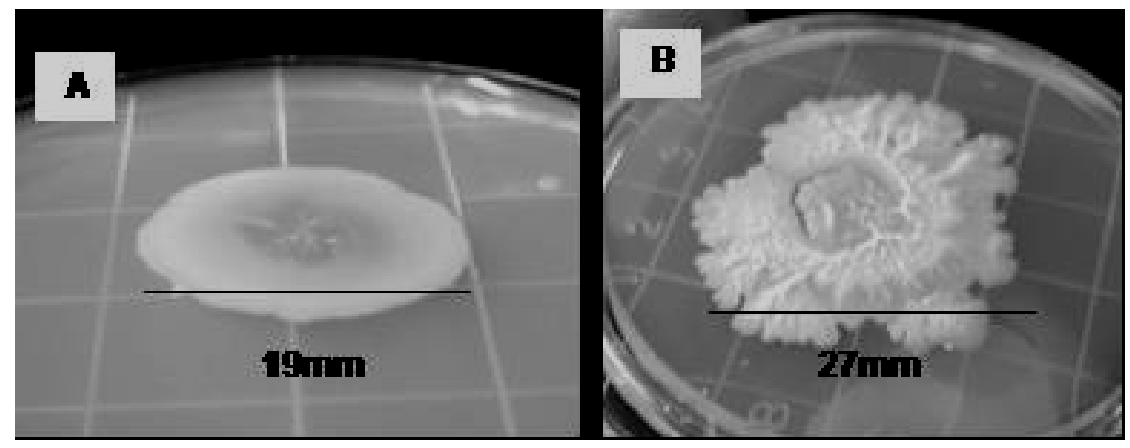

Figure 7 - Bacillus atrophaeus growth (TSA, $36^{\circ} \mathrm{C}, 5$ days) from spores produced (A) by sporulation in agar (B) by SSF. 


\section{DISCUSSION}

The ability of the Bacillus atrophaeus for growing on a SSF probably is due to a function of its requirements of water activity, their capacity of adherence and their ability to assimilate the complex substrates used. Substrate moisture content is a significant process condition, especially for bacteria, because these organisms are considered the most suitable for growth in higher moisture contents. In SSF the aeration has essentially the functions: oxygen supply for aerobic metabolism, removal of $\mathrm{CO}_{2}$, heat, water vapor and volatile components produced during the metabolism; regulate the substrate temperature and the moisture level. The exchange of $\mathrm{O}_{2}$ and $\mathrm{CO}_{2}$ between the solid and the gas phase depends on those factors that increase the contact surface between the phases like: additional aeration generated by forced step of sterile air, agitation and moisture level of the substrate (Gervais and Molin, 2003). In a column bioreactor, the substrate humidity changes during fermentation owing to the saturated air passing through the medium, consequently, it was very important to define optimal conditions for these parameters in order to attain high growth and sporulation (Vandenberghe et al., 2004; Prado et al., 2005). Bacterial performance often occurs at high moisture levels. However, studies in SSF involving strains of Bacillus for the production of enzymes, as have been observed as in aerobic SSF fungal studies, that increasing water content beyond the optimal level resulted in slowed growth and limited product formation, suggesting that the diffusion of gaseous oxygen into the larger liquid phase (within the interparticle spaces) was not adequate to support effective microbial respiration (Babu and Satyanarayana, 1996; Mamo and Gessesse, 1999). The observed results suggested that the efficiency of nutrients and oxygen transfer processes was sufficient to allow a good diffusion of solutes and gas, and promote the same cellular growth in the differents conditions: aerated columns, no aerated columns and flasks.

The water activity of the substrate did not change with moisture content and the fermentation time in all experiments. Knowing that water activity measures the thermodynamic potential of water in the system, and is a function of the type and amount of solutes present in the water and the water adsorption properties of the substrate and that moisture content is a direct measurement of the amount of water in the system (Chinn et al., 2007) it could be considered that the moisture content treatments investigated in this study had identical thermodynamic states because the water activities were identical. It was observed by Grajek and Gervais (1987) with sugar-beet pulp and by Chinn et al. (2007) with paper pulp sludge as support.

It was largely cited that the beginning of sporulation can be triggered by multiple environmental signals, like nutrient starvation and high cell densities, which cause a specific subpopulation of cells to switch on an elaborate genetic program resulting in spore formation (Sonenshein, 2000; Piggot and Losick 2002; Errington, 2003; Veening, 2007). In this kinetic study it was observed that the total sugar consumption was 0.83 up to $0.95 \mathrm{~g}$ and it was noticed that the sporulation started when there were still large supply of carbohydrates, indicating that in this case, the reduction or the lack of the carbon source was not the inducing sporulation factor. An increase in $\mathrm{pH}$ until the seventh day of incubation (between 1.4 and 1.6), was observed, followed by a slight decrease between the seventh and ninth day (0.2 to 0.5$)$. Warriner and Waites (1999) also observed an increase in $\mathrm{pH}$ during sporulation of Bacillus subtilis on agar, attributing it to the absorption of acids formed for the production of new proteins. In plastic bag fermentation it was found almost exclusively the presence of spores at the end of the process, which can be justified by a higher rate of sporulation or by the absence or reduction of the partial germination of produced spores, but this factor gave no significant difference in total number of spores produced, in relation to the process implemented in a flask bioreactor.

The best conditions for spore production (3.3 $10^{10}$ CFU.g dry matter ${ }^{-1}$ ) in column bioreactor was $80 \%$ of initial humidity and no aeration. In Erlenmeyer flasks and plastic bags the best sporulation production reached 1.7 up to $4.710{ }^{10} \mathrm{CFU} . \mathrm{g}$ dry matter $^{-1}$ with $93-91 \%$ of initial moisture, respectively. No similar report about B.atrophaeus kinetic's spore production in differents bioreactors and conditions of aeration were found in the literature to compare the obtained results.

The spores obtained from SSF showed growth characteristics as biofilm formation. Nagel et al. (2002) cited by Plomp et al. (2005) stated that: 
"Although very little is known about the mechanistic basis of differences observed is well known that gene expression in SSF may be different from that in other kind of fermentation". A new category of SSF was proposed by Gutierrez-Correa and Villena (2003): fermentation by the accession to the surface or fermented by biofilm. This category has been proposed in the application of the concept of biofilm (community of microorganisms attached to surfaces) in the solid state fermentation. The membership and subsequent differentiation of gene expression, creating different phenotypes observed in the microorganisms were not adhered cited as characteristics of this type of fermentation and additional studies should be done to elucidate this induction pathway.

\section{ACKNOWLEDGEMENTS}

The financial resources for the conduction of this study were supported by the project BioAgroPar financed by FINEP, Fundo Paraná SETI/PR, and Fundação Araucária/PR; and by CNPq/Brazil.

\section{RESUMO}

Estudos foram conduzidos para avaliar a produção de esporos de Bacillus atrophaeus, em escala laboratorial, por fermentação em estado sólido (FES) em biorreatores de coluna (aeração forçada), sacos plásticos e frascos tipo Erlenmeyer (aeração por difusão), usando bagaço de cana como suporte e melaço de soja como substrato. Diferentes teores de umidade $(84 \%, 86 \%$ e $88 \%, 89 \%, 91 \%$ e $93 \%)$ e taxas de aeração $(30 \mathrm{~mL} / \mathrm{min}, 45 \mathrm{~mL} / \mathrm{min}$, $60 \mathrm{~mL} / \mathrm{min}$ e $90 \mathrm{~mL} / \mathrm{min}$ ) foram estudados. A melhor condição para a produção de esporos no biorreator de coluna $\left(3.3 \times 10^{10} \mathrm{CFU}^{-1}{ }^{-1}\right.$ matéria seca) foi $80 \%$ de umidade inicial, sem aeração. Em frascos Erlenmeyer e sacos de plástico a melhor esporulação foi na faixa de 1.7 a $4.7 \times 10^{10} \mathrm{CFU} . \mathrm{g}^{-}$ ${ }^{1}$ matéria seca, com $88-93 \%$ de umidade inicial. A taxa de aeração não teve efeito significativo sobre o rendimento da esporulação. A umidade inicial apresentou efeito significativo relacionado ao tipo do biorreator. O estudo da cinética da esporulação demonstrou a possibilidade de reduzir o tempo de incubação para esporulação em dois dias.

\section{REFERENCES}

Association for the Advanced of Medical Instrumentation-ANSI/AAMI/ISO $11138 \quad$ (1994), Sterilization of Health Care Products-Biological Indicators. AAMI Publications, Annapolis Junction, MD,EUA

Babu, K. R. and Satyanarayana, T. (1996), Production of bacterial enzymes by solid state fermentation. J.Sci.Ind.Res., 55, 464-467

Blakistone, B.; Chyate, R., Kauttek, D.; Charbonneau, J.; Suit, K. (1999), Efficacy of Ozona Active against Selected Spore Formers. J. Food Prot., 62 (3), 262267.

Branda, S. S.; González-Pastor, J. E.; Ben-Yehuda, S.; Losick, R.; Kolter, R. (2001), Fruiting body formation by Bacillus subtilis. Proceedings of the National Academy of Sciences USA (PNAS), 98, 11621-11626

Chinn, M. S.; Nokes, S. E.; Strobel ,H. J. (2007), Influence of process conditions on end product formation from Clostridium thermocellum 27405 in solid substrate cultivation on paper pulp sludge. Bioresource Technology, 98 (11), 2184-2193

Christensen, E. A. and Kristensen, H. (1979), Biological Indicators for the Control of Ethylene Oxide Sterilization. Acta Pathol Microbiol Scand [B], 87 (3), 147-54.

Errington, J. (2003), Regulation of endospore formation in Bacillus subtilis. Nat Rev Microbiol., 1, 117-126

Fritze, D. and Pukall, R. (2001), Reclassification of bioindicator strains Bacillus subtilis DSM 675 and Bacillus subtilis DSM 2277 as Bacillus atrophaeus. Int.J.Syst.Evol.Microbiol., 51 (1), 35-37

Gale, P.; Pitchers, R.; Gray, P. (2002), The Effect of Drinking Water Treatment on the Spatial Heterogeneity of Micro-Organisms: Implications for Assessment of Treatment Efficiency and Health Risk. Water Res. 36 (6), 1640-1648

Gervais, P. and Molin, P. (2003), The role of water in solid-state fermentation. Biochemical Engineering Journal, Pandey, A. (1992), Recent developments in solid state fermentation. Process Biochem., 27, 109117 (2-3), 85-101. doi: 10.1016/S1369$703 \mathrm{X}(02) 00122-5$.

Grajek, W. and Gervais, P. (1987), Effect of the sugarbeet pulp water activity on the solid-state culture of Trichoderma viride TS. Appl. Microbiol.Biotechnol., 26, 537-541

Gutiérrez-Correa, M. and Villena, G. K. (2003), Surface adhesion fermentation: a new fermentation category. Revista Peruana de Biología, 10 (2) 113-124

Hoxey, E.V.; Soper, C. J.; Davies, D. J. (1985) Biological indicators for low temperature steam formaldehyde sterilization: effect of defined media on sporulation, germination index and moist heat resistance at 110 degrees $\mathrm{C}$ of Bacillus strains. Journal of Applied Bacteriology, 58, 207-14 
HSTAT - Health Services/Technology Assessment Text (2002) AHRQ Evidence Reports. Number 59. Bioterrorism Preparedness and Response: Use of Information Technologies and Decision Support Systems. In: http://www.ncbi.nlm.nih.gov/books/bv.fcgi?rid=hstat 1.section.78786. Accessed: July 2007

Mamo, G. and Gessesse, A. (1999), Effect of cultivation conditions on growth and a-amylase production by a thermophilic Bacillus sp. Letters in Applied Microbiology, 29, 61-65

Mudgett, R. E. (1986), Solid State Fermentation. InDemain, A. L.; Solomon, N. A. Manual of Industrial Microbiology and Biotechnology, American Society for Microbiology, Washington, pp. 66-83.

Nagel, F. J. I.; Tramper, J.; Van As, H.; Rinzema, A.(2002), Water and glucose gradients in the substrate measured with NMR imaging during solidstate fermentation with Aspergillus oryzae. Biotechnology and Bioengineering, 79, 653-666

Nelson, N. (1944), A fotometric adaptaion of Somogyi method for the determination of glucose. J.Biol.Chen., 153, 375-80

Penna, T. V.; Machoshvili, I. A. E.; Aquarone, E. (1996), Thermal Resistance of Bacillus Stearothermophilus Spores on Strips Previously Treated with Calcium. PDA Journal of Pharmaceutical Science and Technology, 50 (4), 227237

Penna, T. C. V.; Mazzola, P. G.; Martins, A. M. S. (2001) The Efficacy of Chemical Agents in Cleaning and Disinfection Programs. BMC Infect Dis., 1 (1), 16

Piggot, P. J. and Losick, R. (2002), Sporulation genes and intercompartmental regulation. In- Sonenshein A, L.; Losick, R.; Hoch, J. A. (eds) Bacillus subtilis and its Closest Relatives: From Genes to Cells, American Society for Microbiology, Washington DC, pp 483517 .

Plomp, M.; Leighton, T. J.; Wheeler, K .E.; Malkin, A. J.(2005), The high-resolution architecture and structure dynamics of Bacillus spores. Biophysical Journal, 88, 603-608.

Prado, F. C.; Vandenberghe, L. P. S.; Soccol, C. R. (2005), Relation between Citric Acid Production by Solid State Fermentation from Cassava Bagasse and Respiration of Aspergillus niger LPB 21 in Semi- pilot Scale. Braz Arch of Bio.l and Technol., 48, 2936

Raimbault, M. (1988), General and microbiological aspects of solid substrate fermentation. Electro. J. Biotechnol., 1 (3), 174-188

Redmond, C.; Baillie, L. W.; Hibbs, S.; Moir, A.J. (2004), Identification of proteins in the exosporium of Bacillus anthracis. Microbiology, 150, 355-363

Soccol, C. R. ; Stertz, S.C.; Raimbault,M.; Pinheiro, L.I. (1995), Biotransformation Of Solid Waste From Cassava Starch Production By Rhizopus In Solid State Fermentation. Part I - Optimization Of The Culture Conditions And Growth Kinetics. Braz. Arch of Biol. and Technol, 38, 1311-1318

Sonenshein, A. L. (2000), Control of sporulation initiation in Bacillus subtilis. Curr Opin Microbiol., 3, 561-566

Sella, S. R. ; Dlugokenski, R. E.; Guizelini, B. P.; Vandenberghe, L.; Medeiros, A. B. P.; Pandey , A.; Soccol, C. R. (2008), Selection and Optimization of Bacillus atrophaeus Inoculum Medium and its Effect on Spore Yield and Thermal Resistance. Appl Biochem Biotechnol. DOI 10.1007/s12010-008-82063.

U.S.P. 29 (2005), Chapter 55.Biological IndicatorsResistance and Performance Tests. In - The United States Pharmacopeia. 29 ed rev. Rockville United States Pharmacopeial Convencion, pp. 2501 -2503.

Vandenberghe, L. P.S.; Soccol,C.R.; Prado,F.C.; Pandey, A.(2004), Comparison of Citric Acid Production by Solid-State Fermentation in Flask, Column, Tray, and Drum Bioreactors. Appl. Biochem. Biotechnol. - Part A Enzyme Eng. Biotechnol., 118 (1-3), 293-303.

Veening, J. (2007), Phenotypic variation in Bacillus subtilis: bistability in the sporulation pathway. Enschede: Print Partners Ipskamp, Proefschrift Rijksuniversiteit Groningen, Nederlands.

Vries, Y. P.; Atmadja, R. D.; Hornstra, L. M.; Devos, W. M.; Abee, T. (2005), Influence of glutamate on growth, sporulation, and spore properties of Bacillus cereus ATCC 14579 in a defined medium. Appl Environ Microbiol., 71, 3248-3254

Warriner, K. and Waites, W. M. (1999), Enhanced sporulation in Bacillus subtilis grown on Medium containing Glucose: Ribose. Letters in Applied Microbiology, 29, 97-102 